\title{
Analisis Strategi Digital Marketing dalam Pemasaran Album K-Pop (Studi Kasus : Weverse Shop - BTS)
}

\author{
Aisyi Syafikarani ${ }^{1}$ \\ ${ }^{1}$ Telkom University \\ ${ }^{1}$ aisyisyafikarani@ telkomuniversity.ac.id
}

\begin{abstract}
Abstrak
Pertumbuhan internet yang sangat cepat telah mengubah beberapa produsen seperti BigHit Official Shop dalam menjalankan bisnisnya, mengubah cara dalam berkomunikasi serta berinteraksi dengan konsumen dan tentunya juga mengubah dalam perancangan strategi pemasarannya menuju ke arah digital marketing. Hal ini dapat dilihat dengan dirilisnya Weverse Shop sebagai aplikasi yang menyediakan merchandise, tiket konser, hingga album BTS. Oleh sebab itu penelitian ini bertujuan untuk menganalisis menganai strategi digital marketing aplikasi Weverse Shop dengan mengunakan matrix SWOT. Penelitian ini termasuk dalam penelitian kualitatif dengan pencarian data dari studi literatur dan studi lapangan melalui dokumentasi dan wawancara. Kemudian data yang sudah diperoleh dianalisis dengan menggunakan matrix SWOT. Hasil dari penelitian ini menunjukkan bahwa BigHit Official Shop perlu menyusun strategi digital marketing dengan menghindari ancaman dan memperkecil kelemahan, serta strategi yang menyesuaikan dengan kekuatan dan peluang yang ada. Seperti memperkuat pangsa pasar, mengembangkan varian produk serta konten aplikasi Weverse Shop, serta menonjolkan keunggulan aplikasi dan kemudahan transaksi dalam memperoleh produk K-Pop official. Hasil dari penelitian ini dapat dijadikan acuan dalam perkembangan pemasaran, khususnya digital marketing dengan memanfaatkan perkembangan teknologi pada masa kini.
\end{abstract}

Kata Kunci : strategi, pemasaran, digital marketing, album K-Pop, Weverse Shop

\begin{abstract}
Fast growth of the internet has changed several manufacturers such as BigHit Official Shop in running their business, changing the way they communicate and interact with consumers and of course also changing the design of their marketing strategies towards digital marketing. This can be seen with the release of Weverse Shop as an application that provides merchandise, concert tickets, and BTS albums. Therefore, this study aims to analyze the digital marketing strategy of the Weverse Shop application using the SWOT matrix. This research is included in qualitative research by searching data from literature studies and field studies through documentation and interviews. Then the data that has been obtained is analyzed using the SWOT matrix. The results of this study indicate that BigHit Official Shop needs to develop a digital marketing strategy by avoiding threats and minimizing weaknesses, as well as strategies that adapt to existing strengths and opportunities. Such as strengthening market share, developing product variants and content of the Weverse Shop application, and highlighting application advantages and ease of transactions in obtaining official $K$-Pop products. The results of this research can be used as a reference in marketing developments, especially digital marketing by taking advantage of current technological developments.
\end{abstract}

Keywords: marketing strategy, digital marketing, K-Pop albums, Weverse Shop 


\section{PENDAHULUAN}

Budaya Korea sangat berkembang pesat diseluruh penjuru dunia dalam dua dekade terakhir ini, keberadaannya yang berhasil diterima oleh seluruh masyarakat global melahirkan sebuah fenomena yang dikenal dengan "Korean Wave", dimana Korean Wave itu sendiri identik dengan musik, drama, hingga variety shows yang dikemas dengan sentuhan budaya Korea dan menyasar kaum millennial.

Salah satu produk Korean Wave yang sangat diminati oleh kaum millennial yaitu musik pop Korea atau yang lebih dikenal dengan sebutan K-Pop. Dimana K-Pop ini telah menjadi salah satu sub-sektor hiburan yang mengangkat perekonomian Korea Selatan (Egsaugm, 2020). Salah satu group KPop yang memiliki prestasi dalam kancah musik internasional yaitu BTS, Bangtan Seonyondan atau dikenal juga dengan sebutan Bangtan Boys. Grup tersebut dibentuk oleh agensi BigHit Entertainment pada tahun 2013. Kini mereka memiliki penggemar atau fandom yang kuat dan memiliki pengaruh yang cukup besar bernama A.R.M.Y singkatan dari Adorable Representative M.C for Youth.

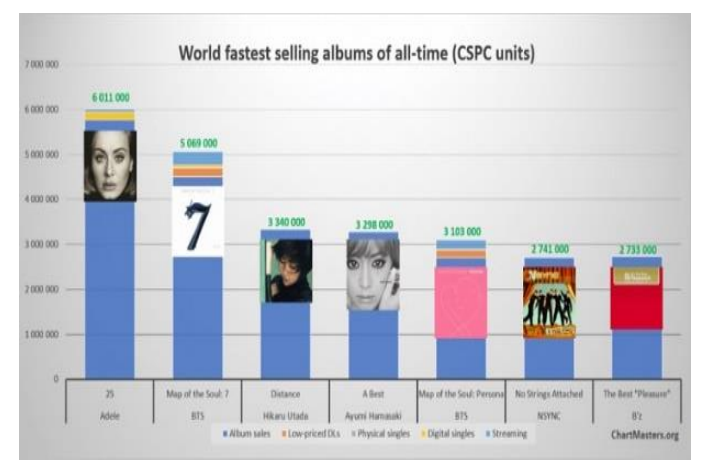

Gambar. 1. Grafik world fastest selling albums of all-time

Keberhasilan BTS ini selaras dengan kualitas dari musik-musiknya yang dituangkan dalam bentuk album dari tahun 2013 hingga sekarang, seperti 2 Cool 4 Skool, O!RUL8,2? (2013), Skool Luv Affair (2014), Dark \& Wild (2014), Wake Up, Danger (Japanese), HYYH pt.1 (2015), HYYH pt.2 (2016), WINGS (2016), YNWA (2017), Love Yourself/Her (2017), Love Yourself/Tear (2018), Love Yourself/Answer (2019), MOTS/Persona
(2019), MOTS/7 (2020), dan BE (2020).

Menurut perhitungan Chartmaster, album BTS MOT/7 berhasil menduduki chart nomor dua setelah penyanyi Adele, dengan perolehan sebesar 5.069.000 unit.

Hal ini membuktikan bahwa album fisik BTS sangat diminati oleh penggemarnya yang tersebar di berbagai belahan dunia. Penjualan album BTS di Korea Selatan, mencapai 3,1 juta unit. Di Jepang behasil menjual sebanyak 300 ribu unit hanya dalam kurun waktu tujuh hari. Sementara 500 ribu unit berhasil terjual di Asia. Bahkan di Eropa juga mendapatkan angka penjualan yang fantastis mencapai 130 ribu unit dan Amerika sebesar 347 ribu unit.

Dengan perkembangan teknologi yang sangat pesat, kini cara memperoleh album yang berada di Korea Selatan tersebut dapat dengan mudah didapatkan meskipun berada di negaranegara lain yang berjauhan. Akses dalam mendapatkan album fisik BTS ini juga didorong dengan perkembangan digital marketing yaitu kegiatan pemasaran sebuah brand atau produk lebih memanfaatkan media digital atau internet (Pangestika, 2020). Dengan dirilisnya Weverse Shop yaitu aplikasi khusus yang dibuat oleh BigHit Official Shop, mereka sedikit demi sedikit sudah mulai meninggalkan pemasaran secara konvensional dan beralih ke media digital, dan hal ini dirasa sangat relevan dengan penjualan dalam tingkat global seperti penjualan album BTS yang menyasar A.R.M.Y di berbagai negara. Dengan digital marketing ini diharapkan dapat mendatangkan banyak manfaat yaitu kecepatan dalam penyebaran, jangkauan yang lebih luas dan murah sehingga lebih efektif, serta dapat menarik konsumen secara cepat dan tepat.

Weverse shop merupakan aplikasi online yang menjual berbagai macam barang-barang BTS mulai dari ARMY Bomb, merchandise, tiket konser, hingga album. Penjualan pada Weverse Shop bersifat internasional, sehingga penggemar dari negara manapun dapat mengakses dan melakukan transaksi melalui Weverse Shop. Dengan adanya aplikasi ini sangat membantu para penggemar karena mereka dapat dengan mudah dan cepat mendapatkan album official langsung dari store resmi. 


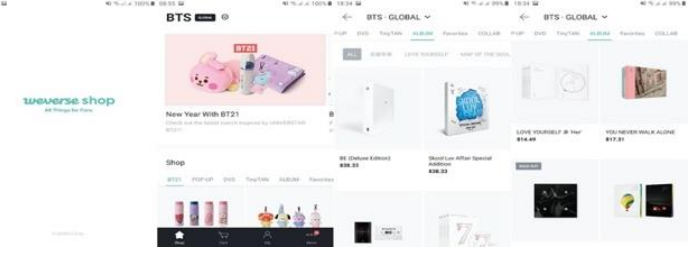

Gambar. 2. Tampilan aplikasi Weverse Shop

Jika pada penelitian sebelumnya banyak membahas mengenai pengaruh digital marketing terhadap pengaruh minat beli seperti penelitian yang dilakukan oleh Alya Rahmadhanty dengan judul "Pengaruh Digital Marketing terhadap Minat Beli Album Musik Korean Pop, Studi pada Penggemar Musik Pop" yang lebih menitik beratkan pada minal beli konsumen (Rahmadhanty, 2020), maka pada penelitian ini lebih mengkaji mengenai digital marketing dengan melihat faktor-faktor eksternal yang menajdi peluang dan ancaman, serta faktor-faktor internal yang menjadi kekuatan dan kelemahan dari aplikasi Weverse Shop, sehingga didapatkan strategi digital marketing yang sesuai. Untuk mencapai hasil tersebut penelitian ini akan menggunakan teori matrix SWOT yang terdiri dari strength, weakness, opportunity, dan threats. Hasil dari penelitian ini dapat dijadikan acuan dalam perkembangan pemasaran dengan memanfaatkan perkembangan teknologi pada masa kini.

\section{METODE}

Pada penelitian ini, melihat adanya pola khusus yang kemudian dikembangkan ke arah pola yang lebih umum dan bertujuan untuk menghasilkan hipotesis dari dilakukannya penelitian lapangan, oleh sebab itu penelitian ini dimasukkan dalam kategori penelitian kualitatif. Penelitian ini bertujuan untuk mengkaji mengenai bagaimana strategi digital marketing dalam pemasaran album K-Pop dengan studi kasus Weverse Shop sebagai aplikasi penjualan online album BTS. Digunakan sudut pandang orang luar yang berjarak untuk menjelaskan adanya fenomena yang sedang berkembang di masyarakat, secara sederhana penelitian ini mengacu pada pandangan peneliti yang didukung oleh beberapa literatur dan pendekatan teori SWOT dan digital marketing.
Dalam menganalisis strategi digital marketing pada penjualan album K-Pop BTS, metode penelitian terbagi menjadi beberapa bagian sebagai berikut :

\section{a. Studi Kasus}

Metode yang diterapkan pada penelitian ini yaitu studi kasus pada aplikasi Weverse Shop yang dikeluarkan oleh BigHit Official Shop karena aplikasi tersebut memenuhi kesesuaian dengan tujuan dan kemudahan teknis dalam penelitian. Selain karena memiliki aplikasi tersendiri dalam hal penjualan, dipilihnya Weverse Shop dan BTS juga dikarenakan keberhasilan penjualan album BTS yang sangat tinggi dan menjangkau negara-negara di seluruh dunia. Aplikasi ini juga sudah diunduh lebih dari $1 \mathrm{M}$ pengguna.

\section{b. Teknik Pengumpulan Data}

Data yang dibutuhkan dalam penelitian ini dikumpulkan melalui dua cara yaitu :

- Studi Kepustakaan

Dalam penelitian ini studi kepustakaan digunakan dalam memperoleh data sekunder yang bertujuan dalam memperkuat penelitian. Studi kepustakaan ini didapat melalui buku, artikel, jurnal, dan beberapa literatur pendukung dari situs internet.

- Studi Lapangan

Studi lapangan dilakukan dengan tujuan untuk memperoleh data primer yang dilakukan melalui dokumentasi dan wawancara. Dokumentasi yang dilakukan dalam penelitian ini yaitu mengumpulkan beberapa foto tampilan dari aplikasi Weverse Shop. Sedangkan wawancana dilakukan untuk memperoleh respon target audiens mengenai aplikasi Weverse Shop. Subjek dipilih secara purposive berdasarkan pada aktivitas dan kesediaan mereka untuk mengeksplorasi pengalaman mereka saat berbelanja album BTS dengan menggunakan aplikasi Weverse Shop.

c. Teknik Pengolahan dan Analisis Data

Pada tahap ini data yang sudah didapatkan, dianalisis dalam beberapa tahap seperti yang diungkapkan oleh Miles dan Huberman dengan teorinya yang disebut analisis data interaktif (Miles, 1992) yang terdiri dari :

1. Reduksi Data

Mereduksi data berarti merangkum dan memilih hal-hal utama, dan memfokuskan 
pada hal-hal yang penting, serta mencari polanya, sehingga data yang telah direduksi dapat memberikan gambaran yang jelas dan mempermudah penelitian untuk pengelompokan data selanjutnya dan mencari data tambahan apabila diperlukan.

\section{Penyajian Data}

Penyajian data pada penelitian ini akan ditampilkan dalam bentuk tabel dan uraian bersifat naratif yang menyampaikan hubungan antar kategori dengan menggunakan teori matrix SWOT yang terdiri dari :

- Strategi SO (Strengths-Opportunies)

Strategi ini dibuat berdasarkan pada jalan pikir perusahaan yaitu dengan memanfaatkan seluruh kekuatan untuk merebut dan memanfaatkan peluang sebesar-besarnya.

- Strategi ST (Strengths-Threats)

Strategi dalam menggunakan kekuatan yang dimiliki perusahaan untuk mengatasi ancaman.

- Strategi WO (Weakness-Oppotunies)

Strategi ini diterapkan berdasarkan pada pemanfaatan peluang yang ada dengan cara meminimalkan peluang yang ada.

- Strategi WT (Weakness-Threats)

Strategi ini didasarkan pada kegiatan yang bersifat defensif dan berusaha meminimalkan kelemahan yang ada serta menghindari ancaman.

Sehingga akan memudahkan untuk memahami apa yang terjadi, merencanakan apa yang akan dilakukan selanjutnya berdasarkan pada apa yang sudah dipahami.

\section{Penarikan Kesimpulan}

Setelah proses analisis data, maka tahap selanjutnya yaitu penarikan kesimpulan yang menjawab rumusan masalah dari penelitian sehingga didapatkan hasil yang dapat bermanfaat untuk perkembangan keilmuan.

\section{HASIL DAN PEMBAHASAN}

Marketing atau pemasaran merupakan sebuah kegiatan yang tidak dapat dipisahkan dari kehidupan sosial ekonomi masyarakat modern. Menurut AMA (The American Marketing Association) mengatakan bahwa pemasaran merupakan proses perencanaan dan pelaksanaan konsepsi, harga, promosi, dan distribusi ide, barang dan jasa untuk menciptakan pertukaran yang memuaskan individu serta tujuan organisasi (Morissan, 2010). Dari definisi ini dapat diketahui bahwa pertukaran merupakan konsep utama dalam kegiatan pemasaran.

Seiring dengan perkembangan teknologi, kini trend dunia pemasaran semakin bervariasi menuju ke arah digital marketing, dengan memanfaatkan internet. Pertumbuhan internet yang sangat cepat telah mengubah cara perusahaan dalam menjalankan bisnisnya, mengubah cara berkomunikasi dan berinteraksi dengan konsumen dan tentunya juga mengubah dalam perancangan strategi pemasarannya. Oleh sebab itu pada penelitian ini akan dianalisis menganai strategi digital marketing aplikasi Weverse Shop dengan mengunakan matrix SWOT.

\section{Identifikasi faktor-faktor strategi internal dan eksternal Weverse Shop}

1. Faktor Internal

Faktor internal merupakan analisa yang dilakukan untuk menilai berbagai hal relevan yang terlibat atau bertanggung jawab dalam proses penawaran barang atau jasa ke pasaran (Morissan, 2010) yang terdiri dari analisis kekuatan (strength) serta kelemahan (weakness) dari Weverse Shop.

a. Kekuatan (strength)

- Tampilan (UI) dan kelengkapan penjelasan produk

Kelebihan dari aplikasi Weverse Shop ini berada pada tampilan UI yang memiliki layout sederhana sehingga memudahkan pengguna dalam mengoperasikannya. Selain itu juga penjelasan mengenai produk yang sangat detail sehingga meskipun pembelian secara online, konsumen sudah dapat mengetahui mengenai item-item yang didapatkan beserta spesifikasi ukurannya.

- Fitur "Announcements" produk baru yang update

Kelebihan lain dari Weverse Shop yaitu karena ia memanfaatkan media digital berupa aplikasi resmi sehingga jika ada produk terbaru, aplikasi ini yang pertama kali mengeluarkan atau menginformasikan ke khalayak. Sehingga apabila seseorang 
menginstal aplikasi Weverse Shop di handphone miliknya, mereka akan mendapatkan notifikasi mengenai produk baru yang dikeluarkan tersebut. Hal ini membuat konsumen, khususnya A.R.M.Y merasa lebih eksklusif.

- Terdapat fitur "Return and Exchanges"

Karena Weverse Shop merupakan aplikasi resmi maka apabila terdapat kerusakan barang, konsumen dapat mengembalikan dan menukar produk melalui fitur "Return and Exchanges", sehingga dapat dipertanggungjawabkan mengenai kondisi produk.

- Memudahkan dalam memperoleh produk official

A.R.M.Y yang tersebar di berbagai negara pada awalnya cukup sulit untuk mendapatkan produk-produk BTS yang berada di Korea Selatan. Namun dengan adanya aplikasi Weverse Shop yang memanfaatkan kemajuan dunia teknologi digital, membuat penggemar yang memiliki keterbatasan jarak menjadi mudah dalam mendapatkan produk-produk official BTS secara langsung dari official store.

- Terpercaya

Di era penjualan secara online, Weverse Shop dinilai lebih terpercaya karena merupakan aplikasi resmi dari BigHit Official Shop. Sehingga hal ini menjadi poin kekuatan dari Weverse Shop itu sendiri. Berdasarkan hasil wawancara juga diungkapkan bahwa hal pertama yang menjadi pertimbangan penggemar mengapa menggunakan aplikasi Weverse Shop karena mereka dalam membeli produk official secara online yang pertama dipertimbangkan yaitu mengenai terpercaya atau tidaknya platform online atau lokasi pembelian, begitu juga dengan keaslian produk yang terjamin

- Kemanan pengiriman

Pengemasan produk yang sangat terjaga serta pengiriman yang terpercaya, membuat proses pengiriman aman. Karena pengiriman produk langsung di prosesdari store menuju alamat setiap konsumen sehingga lebih eksklusif. b. Kelemahan (weakness)

- Kurangnya informasi mengenai status pengiriman

Kekurangan dari aplikasi Weverse Shop yaitu saat melakukan pemesanan, informasi mengenai status pengiriman dirasa kurang update, sehingga konsumen terkadang tidak bisa mengetahui progres pemesanan barang. Hal ini didukung dengan pernyataan dari hasil wawancara yang menceritakan pengalamannya saat membeli ARMY Kit melalui Weverse Shop beberapa bulan yang lalu, dimana status pengiriman tidak update secara berkala, sehingga konsumen tidak bisa mengetahui progres pengiriman.

- Kurangnya layanan konsumen

Meskipun pada aplikasi Weverse Shop sudah dilengkapi fitur "Customer Service" dan" FAQ" akan tetapi dirasa masih kurang solutif dalam hal memberikan layanan kepada konsumen karena respon yang membutuhkan waktu lama.

- Keterbatasan jenis mata uang (currency)

Kekurangan lainnya dari Weverse Shop yaitu mengenai mata uang pembayaran yang hanya tersedia beberapa mata uang seperti $U S$ Dollar, South Korean Won, dan Japanese Yen, sehingga menyulitkan penggemar yang tidak memiliki virtual account untuk mata uang asing.

- Kurangnya promosi secara berkala dalam hal pemberian diskon

Weverse Shop hampir tidak pernah ada promosi seperti diskon dalam hal pembelian produknya. Sebagai gantinya mereka biasanya memberikan bonus merchandise tambahan yang hanya bisa didapatkan saat membeli album melalui Weverse Shop.

\section{Faktor Eksternal}

Faktor eksternal merupakan analisa yang digunakan untuk mengetahui citra atas produknya, penilaian pasar, hingga kondisi dari pesaing (Morissan, 2010), yang mencakup peluang (opportunities) dan ancaman (threats).

a. Peluang (opportunities)

- Pangsa pasar yang semakin besar

Semakin suksesnya BTS membuat semakin 
bertambahnya khalayak mengetahui tentang BTS, hal ini juga membuat bertambahnya penggemar yaitu A.R.M.Y dari berbagai negara. Dengan adanya aplikasi secara online ini akan memudahkan penggemar untuk mendapatkan produk-produk BTS.

- Berkembangnya BTS dalam industri musik internasional

Begitu juga dengan perkembangan musik pop Korea dalam industri musik, khususnya BTS yang kini mulai diterima pada industri musik internasional sehingga hal ini membuat musik BTS berpeluang untuk terus berkembang dan menghasilkan banyak album. Dengan fenomena tersebut maka Weverse Shop memiliki peluang yang cukup besar untuk terus dibutuhkan dalam beberapa waktu mendatang.

- Berkembangnya tren koleksi produk K-Pop

Adanya fenomena bahwa kini para penggemar membeli album tidak hanya untuk mendengarkan musik saja melainkan juga untuk mengkoleksi merchandise lainnya yang ada di album, seperti photocard, poster, hingga buku lirik dari masing-masing judul lagu yang dilengkapi pula dengan photoshoot para member. Membuat minat beli konsumen terhadap penjualan album K-Pop semakin tinggi. Hal ini didukung pula dengan data hasil wawancara bahwa beberapa penggemar mengkoleksi album BTS sekitar 5-10 album.

\section{b. Ancaman (threat)}

- Munculnya para pesaing

Dunia pemasaran yang beranjak menuju ke digital marketing juga mendatangkan ancaman bagi Weverse Shop. Ancaman utama dari Weverse Shop yaitu munculnya para pesaing seperti situs web penjualan global contohnya yaitu GMarket (Global Market), serta munculnya jasa titip (jastip) pada media sosial seperti Instagram yang menawarkan harga pengiriman lebih murah dan selalu menginformasikan status pengiriman kepada para konsumennya.

- Biaya pengiriman yang selalu berubah Biaya pengiriman yang selalu berubahubah juga menjadi pertimbangan konsumen dalam membeli produk via Weverse Shop, karena terkadang harga pengiriman menjadi lebih mahal dari pada harga produk yang dibeli.

- Permasalahan teknis seperti crash app saat keluar produk baru

Permasalahan teknis yang sering terjadi pada aplikasi Weverse Shop yaitu crash app pada saat terdapat produk baru yang rilis. Hal ini mungkin dikarenakan banyak pengguna yang mengakses aplikasi tersebut secara global dan bersamaan.

Tabel 1. Matrix SWOT aplikasi Weverse Shop

\begin{tabular}{|c|c|c|}
\hline & $\begin{array}{l}\text { Strenght (S) } \\
\text { - Tampilan } \\
\text { (UI) dan } \\
\text { kelengkapan } \\
\text { penjelasan } \\
\text { produk } \\
\text { - Fitur } \\
\text { “Announcem } \\
\text { ents" produk } \\
\text { baru yang } \\
\text { update } \\
\text { - Terdapat } \\
\text { fitur "Return } \\
\text { and } \\
\text { Exchanges" } \\
\text { - Memudahka } \\
\text { n dalam } \\
\text { memperoleh } \\
\text { produk } \\
\text { official } \\
\text { - Terpercaya } \\
\text { - Keamanan } \\
\text { pengiriman }\end{array}$ & $\begin{array}{l}\text { Weakness } \\
\text { (W) } \\
\text { - Kurangnya } \\
\text { informasi } \\
\text { mengenai } \\
\text { status } \\
\text { pengiriman } \\
\text { - Kurangnya } \\
\text { layanan } \\
\text { konsumen } \\
\text { - Keterbatas } \\
\text { an jenis } \\
\text { mata uang } \\
\text { (currency) } \\
\text { - Kurangnya } \\
\text { promosi } \\
\text { secara } \\
\text { berkala } \\
\text { dalam hal } \\
\text { pemberian } \\
\text { diskon }\end{array}$ \\
\hline $\begin{array}{l}\text { Opportunity } \\
\text { (O) } \\
\text { - Pangsa } \\
\text { pasar yang } \\
\text { semakin } \\
\text { besar } \\
\text { - Berkemba } \\
\text { ngnya } \\
\text { BTS } \\
\text { dalam } \\
\text { industri } \\
\text { musik } \\
\text { internasion } \\
\text { al } \\
\text { - Berkemba } \\
\text { ngnya tren } \\
\text { koleksi }\end{array}$ & $\begin{array}{l}\text { Strategi SO } \\
\text { - Memperkuat } \\
\text { pangsa pasar } \\
\text { - Mengemban } \\
\text { gkan varian } \\
\text { produk serta } \\
\text { konten } \\
\text { aplikasi } \\
\text { Weverse } \\
\text { Shop } \\
\text { - Menonjolkan } \\
\text { keunggulan } \\
\text { aplikasi dan } \\
\text { kemudahan } \\
\text { transaksi } \\
\text { dalam } \\
\text { memperoleh }\end{array}$ & $\begin{array}{l}\text { Strategi WO } \\
\text { - Memaksim } \\
\text { alkan } \\
\text { update } \\
\text { mengenai } \\
\text { status } \\
\text { pengiriman } \\
\text { - Menambah } \\
\text { kan } \\
\text { layanan } \\
\text { konsumen, } \\
\text { seperti fitur } \\
\text { chat } \\
\text { - Menambah } \\
\text { kan } \\
\text { beberapa } \\
\text { jenis mata }\end{array}$ \\
\hline
\end{tabular}




\begin{tabular}{|c|c|c|}
\hline $\begin{array}{l}\text { produk K- } \\
\text { Pop }\end{array}$ & $\begin{array}{l}\text { produk K- } \\
\text { Pop official }\end{array}$ & $\begin{array}{l}\text { uang } \\
\text { (currency) } \\
\text { - Memaksim } \\
\text { alkan } \\
\text { kegiatan } \\
\text { promosi, } \\
\text { misalnya } \\
\text { diskon } \\
\text { pada saat- } \\
\text { saat } \\
\text { tertentu }\end{array}$ \\
\hline $\begin{array}{l}\text { Threats }(\mathbf{T}) \\
\text { - Munculny } \\
\text { a para } \\
\text { pesaing } \\
\text { - Biaya } \\
\text { pengirima } \\
\text { n yang } \\
\text { selalu } \\
\text { berubah } \\
\text { - Permasala } \\
\text { han teknis } \\
\text { seperti } \\
\text { crash app } \\
\text { saat keluar } \\
\text { produk } \\
\text { baru }\end{array}$ & $\begin{array}{l}\text { Strategi ST } \\
\text { - Menetapkan } \\
\text { strategi } \\
\text { pemasaran } \\
\text { - Menampilka } \\
\text { n } \\
\text { keunggulan } \\
\text { produk } \\
\text { khususnya } \\
\text { dalam } \\
\text { pengiriman } \\
\text { barang } \\
\text { - Meningkatka } \\
\text { n kualitas } \\
\text { pelayanan } \\
\text { dalam } \\
\text { penggunaan } \\
\text { Weverse } \\
\text { Shop }\end{array}$ & $\begin{array}{l}\text { Strategi WT } \\
\text { - Meningkat } \\
\text { kan strategi } \\
\text { digital } \\
\text { marketing } \\
\text { yang } \\
\text { efektif dan } \\
\text { efisien }\end{array}$ \\
\hline
\end{tabular}

Dari Analisa matrix SWOT di atas dapat diketahui bahwa antar faktor-faktor saling dibandingkan. Berikut ini merupakan pengembangan strategi digital marketing dari hasil interpretasi analisis SWOT Weverse Shop, yaitu :

\section{Strategi SO (strength-opportunities)}

Strategi berdasarkan pada kekuatan dan peluang yang dimiliki oleh Weverse Shop yaitu:

- Memperkuat pangsa pasar

Pangsa pasar yang semakin besar memiliki peluang untuk memperkuat pangsa pasar tersebut, dengan penyusunan strategi digital marketing yang memadai melalui aplikasi Weverse Shop, seperti memilih pasar yang tepat sasaran serta melihat kemampuan yang dimiliki oleh Weverse Shop.

- Mengembangkan varian produk serta konten aplikasi Weverse Shop

BTS yang kini mulai diterima di kancah musik internasional membuka peluang untuk mengembangkan varian produk serta konten pada Weverse Shop, sehingga dapat memenuhi keinginan dari para konsumen.

- Menonjolkan keunggulan aplikasi dan kemudahan transaksi dalam memperoleh produk K-Pop official

Keunggulan aplikasi dan kemudahan transaksi merupakan pertimbangan utama konsumen dalam menggunakannya. Dan Weverse Shop memiliki keunggulan dan kemudahan tersebut, hal ini harus lebih ditonjolkan lagi sehingga dapat mendukung tren koleksi para penggemar.

2. Strategi WO (weakness-opportunities)

Strategi berdasarkan pada kelemahan dan peluang yang dimiliki oleh Weverse Shop yaitu:

- Memaksimalkan update mengenai status pengiriman

Sebenarnya dalam fasilitas status pengiriman sudah terorganisir dengan baik pada aplikasi Weverse Shop mulai dari tahapan awaiting payment, ordered, to be used, to be picked up, in transit, hingga complete. Namun terkadang status tersebut tidak terupdate dengan baik sehingga perlu untuk dimaksimalkan lagi. Karena mengetahui progres pengiriman juga sangat diperlukan oleh konsumen.

- Menambahkan layanan konsumen seperti fitur chat

Penambahan fitur chat diharapkan dapat menjawab kelemahan dari aplikasi Weverse Shop yang dinilai lambat dalam memberikan respon konsumen. Sehingga dengan adanya fitur ini dapat meningkatkan kepuasan konsumen terhadap aplikasi ini.

- Menambahkan beberapa jenis mata uang (currency)

Mata uang yang tersedia hanya US Dollar, South Korean Won, dan Japanese Yen, sehingga perlu ditambahkan beberapa jenis mata uang lainnya yang bisa diambil dari negara yang membeli album terbanyak setelah 3 negara tersebut, mengingat kini pengguna Weverse Shop sudah dalam rana global. 
- Memaksimalkan kegiatan promosi, misalnya diskon pada saat-saat tertentu

Salah satu yang menarik dan dapat meningkatkan minat beli adalah melalui promosi, salah satunya yaitu dengan pemberian diskon. Karena beberapa pesaing Weverse Shop banyak yang berpromosi dengan memberian diskon dan ini menjadi pertimbangan konsumen untuk lebih memilih platform lain selain Weverse Shop.

\section{Strategi ST (strength-threats)}

Strategi berdasarkan pada kekuatan dan ancaman yang dimiliki dan dihadapi oleh Weverse Shop yaitu:

- Menetapkan strategi pemasaran

Pesaing dari Weverse Shop sangat banyak karena di dukung dengan semakin meleknya khalayak mengenai digital marketing sehingga banyak penjual yang juga memanfaatkan kemajuan teknologi dan internet. Oleh sebab itu, Weverse Shop harus menentukan posisi pasar sasaran dan target-target pemasaran dengan perancanaan yang strategis dengan melihat kekuatan dan peluang yang ada.

- Menampilkan keunggulan produk, khususnya dalam pengiriman barang

Untuk menekan permasalahan mengenai biaya pengiriman yang tidak menentu bisa diimbangi dengan menampilkan keunggulan pengiriman produk pada aplikasi Weverse Shop, sehingga meskipun konsumen membeli produk dengan biaya pengiriman yang tinggi, sebanding dengan kualitas pengiriman yang memadai.

- Meningkatkan kualitas pelayanan dalam penggunaan Weverse Shop

Pelayanan menjadi salah satu faktordalam menentukan keputusan. Sehingga meningkatkan pelayanan yang maksimal maka loyalitas konsumen akan meningkat. Bahkan aplikasi Weverse Shop dapat menarik konsumen baru yang menjadi target sasarannya.

\section{Strategi WT (weakness-threats)}

Strategi berdasarkan pada kelemahan dan ancaman yang dimiliki dan dihadapi oleh Weverse Shop yaitu:
- Meningkatkan strategi digital marketing yang efektif dan efisien

Weverse Shop hendaknya menetapkan strategi digital marketing yang efektif dan efisien, sehingga dapat menghindari ancaman dan memperkecil kelemahan yaitu strategi yang menyesuaikan dengan kekuatan dan peluang yang ada.

\section{SIMPULAN DAN SARAN}

Berdasarkan analisis yang dilakukan dapat diketahui bahwa:

1. Strategi digital marketing yang diterapkan oleh aplikasi Weverse Shop menyasar para penggemar BTS yang tersebar di berbagai negara sehingga membutuhkan platform penjualan produk-produk BTS secara online. Disinilah aplikasi Weverse Shop memiliki peran yang sangat besar dalam menjawab kebutuhan konsumen khususnya para A.R.M.Y.

2. Hasil analisis SWOT dapat diketahui bahwa aplikasi Weverse Shop memiliki peluang dan layak bersaing. Sehingga sangat memungkinkan untuk terus berkembang dan mendapatkan penjualan yang maksimal.

3. Langkah yang dapat diambil selanjutnya dalam pengambilan keputusan untuk strategi digital marketing aplikasi Weverse Shop yaitu dapat dilakukan dengan strategi SO yang memanfaatkan kekuatan dan peluang yang ada. Adapun beberapa strategi-strategi yang dapat dihasilkan dalam pengembangan melalui analisis SWOT pada aplikasi Weverse Shop yaitu:

\section{a. Strategi SO}

Dapat dilakukan dengan memperkuat pangsa pasar yang semakin besar, mengembangkan varian produk serta konten aplikasi Weverse Shop, serta menonjolkan keunggulan aplikasi dan kemudahan transaksi dalam memperoleh produk K-Pop official.

\section{b. Strategi WO}

Dapat dilakukan dengan memaksimalkan update mengenai status pengiriman, menambahkan layanan konsumen, seperti fitur chat, 
menambahkan beberapa jenis mata uang (currency), serta memaksimalkan kegiatan promosi, misalnya diskon pada saat-saat tertentu.

c. Strategi ST

Dapat dilakukan dengan menetapkan strategi pemasaran, menampilkan keunggulan produk khususnya dalam pengiriman barang, serta meningkatkan kualitas pelayanan dalam penggunaan Weverse Shop.

d. Strategi WT

Dapat dilakukan dengan meningkatkan strategi digital marketing yang efektif dan efisien sehingga dapat menghindari ancaman dan memperkecil kelemahan yaitu strategi yang menyesuaikan dengan kekuatan dan peluang yang ada.

\section{DAFTAR PUSTAKA}

Egsaugm. (2020, September 30). Fenomena Korean Wave di Indonesia. Retrieved from EGSA: https://egsa.geo.ugm.ac.id/2020/09/30/fe nomena-korean-wave-di-indonesia/

Pangestika, W. (2020, Januari 1). Pengertian, Kelebihan, Jenis dan Strategi Digital Marketing. Retrieved from Mekari: https://www.jurnal.id/id/blog/mengenaldigital-marketing-konsep-danpenerapannya/

Rahmadhanty, Alya. (2020). Pengaruh Digital Marketing terhadap Minat Beli Album Musik Korean Pop (Studi pada Penggemar Musik Korean Pop). OpenLibrary Telkom University

Miles, M. (1992). Analisis Data Kualitatif Buku Sumber tentang Metode-Metode Baru. Jakarta: UIP.

Morissan. (2010). Periklanan, Komunikasi Pemasaran Terpadu. Jakarta: Prenadamedia Group. 